\title{
Interacting Role of Perceived Service Orientation on Work Family Conflict, Fuel Subsidy Removal and Tax Compliance Behaviour: Evidence from Nigerian SMEs
}

\author{
Augustine Ayuba ${ }^{1}$, Natrah Saad ${ }^{1} \&$ Zaimah Zainol Ariffin $^{1}$ \\ ${ }^{1}$ School of Accountancy, College of Business, Universiti Utara Malaysia, Sintok, Kedah Darul Aman, Malaysia \\ Correspondence: Augustine Ayuba, School of Accountancy, College of Business, Universiti Utara Malaysia, \\ 06010 Sintok, Malaysia. E-mail: ayubaaugustine@yahoo.com
}

Received: November 3, 2015

Accepted: November 18, 2015 Online Published: November 27, 2015

doi:10.5539/ass.v11n28p226

URL: http://dx.doi.org/10.5539/ass.v11n28p226

\begin{abstract}
The paper examined the interacting role of perceived service orientation on the relationship between work family conflict, fuel subsidy removal and tax compliance behaviour in Nigeria. The aim of this paper is to establish whether the interacting role of perceived service orientation will further help in explaining the puzzle of tax compliance in relation to SMEs taxpayers. A total of 281 questionnaires from SMEs in Kaduna and Kano states, North West Nigeria were utilised in this study. Partial Least Squares Structural Equation Modeling (PLS-SEM) was used to test the study hypotheses. As predicted, the findings supported the interacting effect of perceived service orientation on the relationship between work family conflict and tax compliance behaviour, while no interacting effect was found between fuel subsidy removal and tax compliance behaviour. The results have practical implications for relevant tax authorities in creating a new paradigm shift that will ensure effective service orientation in the form of tax education and other form of tax services that could go a long way in minimising the tendency of low level of tax compliance.
\end{abstract}

Keywords: SMEs, tax compliance behaviour, perceived service orientation, work family conflict, fuel subsidy removal

\section{Introduction}

The vision of any government is aiming at achieving a reasonable level of tax compliance as well as maintaining the current compliance rates. Therefore, the fundamental objective of taxation regardless of whether developed, emerging or developing economy is geared towards revenue generation (Cheunjit, 2014). Intrinsically, tax compliance has begun to be a bone of contention for policy makers. Even though, many scholars have emphasized on why people and entities evade their taxes, rather than why remarkable number of people do willingly comply with their tax obligations (Slemrod, 1992). However, issues of tax compliance cut across international borders. It has been statistically revealed that a lingering issue of tax compliance is on the increase on a yearly basis. For instance, the BBC news magazine (2013) revealed that, the UK government lost a huge amount of billions which were traced to the business activities of Amazon, Google and Starbucks units. According to the report, the companies which made a sale of 3.35 billion and 395 million UK pounds only paid 1.8 million and 6 million UK pounds as tax. While Starbucks unit recorded a turnover of 400 million, but engaged in transfer pricing with a sister company in New Zealand. Similarly, in Malaysia, statistics made available by the New Sabah Times English (2013) showed that, Inland Revenue Board Malaysia were able to solve only 1.9 million cases of tax litigations in 2012, which enabled the government to recoup RM2.95 million.

In Nigeria, the issue of tax compliance is not far fetching. Even though, adequate and appropriate mechanisms in terms of tax audit tribunal, tax audits and investigation department in all the State Internal Revenue Service (SIRS) are already in place in order to enhance the level of tax compliance, low level of compliance is still recorded among the Small and Medium Enterprises (SMEs) (Taiwo, 2013). In the same vein, many indexes also showed that Nigeria as a country has been on the page of bottom rungs of global indexes of economic and social development. Among these latest indexes are, "Paying Taxes (2014)", the index, which annually compares tax systems across the world. In 2014, Nigeria was ranked $179^{\text {th }}$ out of 189 countries. According to the ranking Nigeria is better than only few countries in relation to the years of observation which was based on three major 
indicators, namely; total tax rate, number of payments and compliance time. Then, as well, the Coordinating Minister for the Economy and Minister of Finance, lamented that over $65 \%$ of the businesses in the country have not filed their tax returns for the past two years, which has again brought to the fore the issue of low tax compliance in the country (NAN, 2014).

Furthermore, a growing number of reports have also shown that, issues of low level of tax compliance are on the increase in Nigeria. For instance, Tanko (2014), reported that, Kaduna state government alone lost over N18 billion (\$112.5 million) in 2013 in unpaid taxes. This act culminated in the closure of about 25 related number of SMEs over the low level of tax payment. Additionally, Shekari (2014) further reiterated that, out of the six (6) million taxable residents in the state, only 500,000 residents pay their taxes. In another related development, the Chairman of the Task Force on Revenue Generation in Kano State, Nigeria reported that, the state government has sealed up over 29 educational institutions as a result of alleged failure to pay taxes (Muhammad, 2012). As a result, not so much explanation had been empirically offered for why the issues of low level of tax compliance have continued to persist.

Empirically, there were a remarkable number of studies that have correlated both economic and non economic factors on tax compliance behaviour. Some of the economic factors that have received empirical attention in relation to tax compliance over the years include tax rates, the probability of detection, and tax complexity (e.g. Allingham \& Sandmo, 1972; Becker, 1968; Chris, Coleen, \& David, 2000; Fischer, Wartick, \& Mark, 1992; Manaf, Hasseldine, \& Hodges, 2005; Mustafa, 1997; Nur - tegin, 2008; Palil, Hamid, \& Hanafiah, 2013; Palil \& Mustapha, 2011; Saad, 2014; Torgler, 2005). Not much have been written on the direct influence of work family conflict and fuel subsidy removal on tax compliance behaviour, let alone its' interacting effect. However, work family conflict was found to be associated with job performance, organizational commitment, individual commitment, and stress (e.g Aryee, 1992; Frone, Yardley, \& Markel, 1997; Kalliath \& Kalliath, 2013; Kossek \& Ozeki, 1999; Wickens, 1996). Similarly, fuel subsidy removal was also found to impact on the agricultural sector, the cost of production, the cost of transportation, and growth (e.g. Kehinde, Kyade, Felix, Musibau, \& Ishola, 2012; Odemero, 2012). Despite the numerous studies conducted on these factors unfortunately some of the findings were mixed, thus inconclusive (Eisenhauer, 2008; Slemrod, Blumenthal, \& Christian, 2001; Young, 1994). There is actually a dearth of empirical research on the phenomenon of tax compliance in the Nigerian setting, except for few studies, such as Alabede (2012) who studied the factors influencing tax compliance behaviour in Nigeria. However, in that study, the scope was tilted to the taxpayers of the Federal Capital Territory (FCT), thence did not cover the Nigerian SMEs. Similarly, Atawodi and Ojeka (2012) also studied the factors influencing tax compliance behaviour of SMEs taxpayers in the North - Central Nigeria. However the scope was limited to SMEs taxpayers of a single local government (i.e. Zaria).

In the face of these empirical studies, it is surprising that, presently, there is barely an empirical study that examines the interacting role of perceived service orientation on the relationship between work family conflict, fuel subsidy removal and tax compliance behaviour. Relevant literatures indicated that the perceived service orientation is a well established construct that exerts a significant influence on tax compliance behaviour (Gangl et al., 2013). Therefore, perceived service orientation is an important strategy for tax authorities to increase tax compliance (Kirchler, Hoelzl, \& Wahl, 2008). The inclusion of this variable is in line with Kirchler, Muelbacher, Kastlunger, and Wahl (2007) that the relationship between tax compliance behaviour and its determinants may be moderated by certain variables. Due to the importance of this construct, conducting a further study on its underlying causes is imperative. Thus, the present study seeks to extend the existing tax compliance literature by investigating the interacting role of perceived service orientation on the relationship between work family conflict, fuel subsidy removal and tax compliance behaviour from the perspective of Nigerian SMEs. The remainder of this paper is organized as follows. In the next section, we reviewed relevant literature in relation to tax compliance, work family conflict, fuel subsidy removal as well as perceived service orientation. In relating these latent constructs, work family spillover, social exchange, and social influence theories were taken into consideration. In section 3, we described the method used in the present study, followed by presentation of the results in section 4. While discussions and implications of the study were captured in sections 5 and 6 respectively.

\section{Literature Review}

\subsection{Tax Compliance Behavior (TCB)}

According to James and Alley (2002), tax compliance can be seen as the willingness of individuals to act in conformity with the 'spirit' and the 'letter' of the tax law and administration without being coarse. On the other hand, Song and Yarbrough (1978) simply defined tax compliance as the taxpayers' ability and willingness to 
comply with the relevant tax laws and regulations, which are determined by ethics, legal environment and other factors at a given time and place.

Over the years, the meaning of tax compliance keeps changing from country to country as well as among researchers. On this note, tax authorities and multinational organizations are not left out in suggesting a similar and appropriate definition for tax compliance. The Inland Revenue Board Malaysia (IRB) (2009); and Australian Tax Office (ATO) (2009) separately defined tax compliance as taxpayers' ability and willingness to obey the tax laws, declare their actual income annually and pay the right amount of taxes on the due date. The Organization for Economic Co-operation and Development (OECD) (2010), on the other hand, outlined two categorization for the definition of tax compliance, i.e. Technical compliance and administrative compliance. According to their findings, technical compliance has to do with the technical requirement of tax laws in the computation of tax liability, whereas administrative compliance is always in line with the combination of reporting compliance, procedural compliance as well as regulatory compliance. In short, it is generally concerned with complying with the rules relating to lodging and payment of tax. Therefore, compliance is enforced on taxpayers that were unable to pay taxes through the use of other mechanisms such as; threat and application of audit and penalties (OECD, 2010).

In contempt of these, Roth, Scholz, and Witte (1989) defined tax compliance, as the ability to comply with the reporting requirements, which invariably means that, the entity files all required tax returns at the proper time, and the returns accurately report tax liability in accordance with the internal revenue code, regulations and court decisions applicable at the time the returns are filed. An alternative to this definition has been offered by James and Alley (2002) which defined tax compliance as the ability of taxable entities to respond in relation to the spirit as well as the letter of relevant tax laws without the administration or application of enforcement. They consider tax compliance in terms of the tax gap, i.e. The difference between the true entity's income tax liability and that which is finally collected by either voluntary payment or by enforcement.

There were few studies that viewed tax compliance from another dimension. For instance, McBarnet (2003) perceived tax compliance in three dimensions, namely (i) committed compliance, which has to do with the taxpayers' willingness and ability to pay his/her taxes without grudges; (ii) capitulative compliance, willingness to give in and pay taxes and (iii) creative compliance which is an engagement to reduce taxes by taking advantage of possibilities to redefine income and deduct expenditures within the bracket of tax laws. Hence, tax compliance is defined as the willingness of the taxpayers to abide by the tax laws, declare the correct income, claim the correct deductions, relief and rebates and pay all taxes on time (Palil \& Mustapha, 2011). Recently, Geibart (2014) conceived tax compliance as a means of navigating a maze of rules, regulations, exceptions and exemptions, which can leave a tax agent confused, disorientated and often lost when they reach a frustrating dead end. It is of consequence to note from the previous definitions on the usage of some keywords which accompanied their individual or collective assumption, such as 'willingness', ability to pay, obey, act of filing tax returns, declares the correct amount, reporting all income, right amount of tax and timeliness.. To the researchers' knowledge, none of the above definitions borrowed the word "appropriate authority or jurisdiction", because in Nigeria, there are three jurisdictional authority (i.e. Local, State, and Federal government) saddle with the powers to collect taxes un - behalf of the government, as such without identifying the appropriate authority or jurisdiction where the taxpayer supposed to pay his / her taxes, may absolutely result to noncompliance even if the taxpayer has wrongfully complied. In relation to the above discussion, and considering the context in which the study is being conducted, thus in the context of this study; tax compliance is defined as the taxpayers' ability and willingness to obey the tax laws, declare their actual income and pay the right amount of taxes on due date to the appropriate relevant authority or jurisdiction.

\subsection{Work Family Conflict (WFC) and Tax Compliance}

Work family conflict has gained a lot of accolades in the literature. As a result, Greenhaus and Beutell (1985) viewed WFC as a form or type of inter role conflict where one's requirement of role conflict makes it difficult to have a valuable time with the family, or when commitment in the family makes it difficult to be fully engaged at work or to meet individual organizational responsibilities and obligations. Hence, it has been reported that the presence of high WFC may result to low individual, and organizational commitment (for instance the commitment of the organization in relation to tax payment) (Kossek \& Ozeki, 1998). In the same line of action, Wickens (1996) also posits that, stress arising from other aspect of life as well as WFC may lead to additional demands (e.g. Financial obligations to meet family pressure, which may affect tax payment and compliance behaviour of the taxpayer).

Therefore, where the WFC is perceived to be high, attention to organizational obligations (for instance, tax 
compliance) and perceived ability to devote discretionary energy to tax payment and other organizational obligation may not be a conscious priority. Aligning to the tenet of the work family spillover theory (Staines, 1980). The theory states that, either system (i.e. Family or work) may have a spillover effect on the other. In the same vein, George and Brief (1990), further proposes that, satisfaction or dissatisfaction in one area of life may extend to other domains and vice versa. For instance, Nzotta (2007); and Odinkonigbo (2009) in a related but separate study, affirmed that, poverty and the extended family burden (for instance, financial obligations) may be seen as one of the causes of low level of tax compliance in Nigeria. Even though, studies on the effects of WFC on tax compliance are rare. On the basis of the above discussion and drawing from the work family spillover theory, the following is hypothesised:

H1: There is a significant negative relationship between WFC and tax compliance behaviour.

\subsection{Fuel Subsidy Removal (FSR) and Tax Compliance}

According to Ikpeze, Soludo, and Elekwa (2004), Iyobhebhe (2011), and Nwafor, Ogujiuba and Asogwa (2006) FSR is defined as a form of price manipulation where the government fixes the pump price of fuel for sale to consumers and pays the retailer the difference between the actual market price and the regulated or official price per litre. Even though, a number of studies provide empirical evidence on the relationship between FSR and other factors, such as the cost of business operation, and effects on SMEs (Hoai \& Thang, 2013; Hope \& Singh, 1995; Kehinde et al., 2012; Odemero, 2012). While Taiwo (2013) further reiterated that, the FSR will compound extreme pressures on disposable income as well as intensifying further loss of tax revenue and higher cost of enforcing compliance.

Therefore, taxpayers', who experience more hardship in terms of provision of social and other infrastructural facilities, may perceive the government as being unfair to them. As a consequence, it may affect their compliance behaviour negatively. Aligning with social exchange theory, it emphasizes that individuals are psychologically indebted and thus compelled to return benefits they received in material or non-material form to the person that benefited them (Blau, 1964). For instance, if taxpayers' perceived the government to be fair towards investing the revenue derived from the FSR, their behaviour towards tax compliance may tend to change positively. In contrast, if the taxpayers' perceived, the government is not being fair towards reinvesting the proceeds or revenue derived from FSR, the level of compliance may be affected negatively. Thus, drawing from social exchange theory together with other empirical justifications the following is hypothesised:

H2: There is a significant negative relationship between the fuel subsidy removal and tax compliance behaviour.

2.4 Interacting Roles of Perceived Service Orientation on the Relationship between Work Family Conflict, Fuel Subsidy Removal and Tax Compliance behaviour

The nature of work family conflict and fuel subsidy removal on tax compliance behaviour may likely differ according to the way service orientation was perceived by the taxpayers. This section discuses the interacting role of perceived service orientation on the relationship between work family conflict, fuel subsidy removal and tax compliance behaviour. Logically the present study adopted the social influence theory which could align to social learning theory (Bandura, 1977) to explain the interacting effect of perceived service orientation on the relationship between work family conflict, fuel subsidy removal on tax compliance behaviour. Perceived service orientation is defined as the attitude to be helpful, thoughtful, considerate and cooperative (Hogan, Hogan, \& Busch, 1984). Therefore, Kirchler et al. (2008) has identified perceived service orientation as one of the most promising strategy for increasing the level of tax compliance. As such, it has been confirmed that, it is an important mechanism that exerts a potential influence on a number of factors including tax compliance (Gangl et al., 2013), cost efficiency (OECD, 2010), as well as satisfaction (Smith \& Stalans, 1991; Stalans \& Lind, 1997). Hence, drawing upon social influence theory which also has a lineage with Bandura's social learning theory (1977) that was premised on the influence of environment. The theory states that behavior is one of the most important ingredients that has been known to be intentionally or unintentionally influenced by others in the environment. Therefore, individuals do learn from each other as well as through observation, imitation, as well as orientations, which explains human behavior in relation to the continuous exchange interaction between cognitive and behavioral environmental influences. In the same vein, Katz and Lazarsfeld (1955) posit that people interact with other individuals to transmit information and thus, influence each other, and further, that this influence is far more powerful than that previously recognized.

Furthermore, Bandura (1977) documented that, people do not only learn the behavior of others through observing their attitude, but are influenced by the outcomes of their behaviors. In this context, social influence theory identifies an extent of social influence an individual encounters in socialization (for instance, service orientation) as one of the most important variables in determining compliance (Sutinen \& Kuperan, 1999). As a 
result, Hogg and Vaughan (2005) reiterated that, social influence could be aligned to conformity, compliance and obedience. The authors further revealed that, compliance may be influenced by the persuasive ways individuals employed in seeking consent as well as the power individuals perceived to have at their disposal. Power in relation to this study is regarded as the ability to exert influence by the relevant tax authorities through service orientation. This power, according to Raven (1993) may be regarded to informative power (for instance service orientation). Hence, no matter the magnitude of the work family burden encountered by the taxpayers, or the hardship being experience by the taxpayers through fuel subsidy removal, when proper orientations are offered to the taxpayers in the form of tax education, calls and other services may go a long towards enhancing their compliance behaviour. In fact, these arguments suggest that service orientation is an important mechanism for strengthening the compliance behaviour of taxpayers. But, in practical terms, social influence in taxation may not be easily achieved due to different needs or requirements of taxpayers. For instance, an influential SME owner/managers will probably receive more attention from the relevant tax authorities compared to less influential SME owners/managers despite their tax contributions. Additionally, the inclusion of perceived service orientation in the present research is in line with the suggestion of Baron and Kenny (1986) who proposed that an interacting variable need to be introduced, when there is uncertainty regarding the relationship between exogenous and endogenous variables. Thus, in order to fully explain the effects of work family conflict and fuel subsidy removal on tax compliance behaviour, this study suggests that the perceived service orientation might possess some interacting effects on their relationship. On the basis of the foregoing argument the following hypotheses are proposed:

H3: Perceived service orientation will moderate the relationship between work family conflict and tax compliance behaviour.

H4: Perceived service orientation will moderate the relationship between the fuel subsidy removal and tax compliance behaviour.

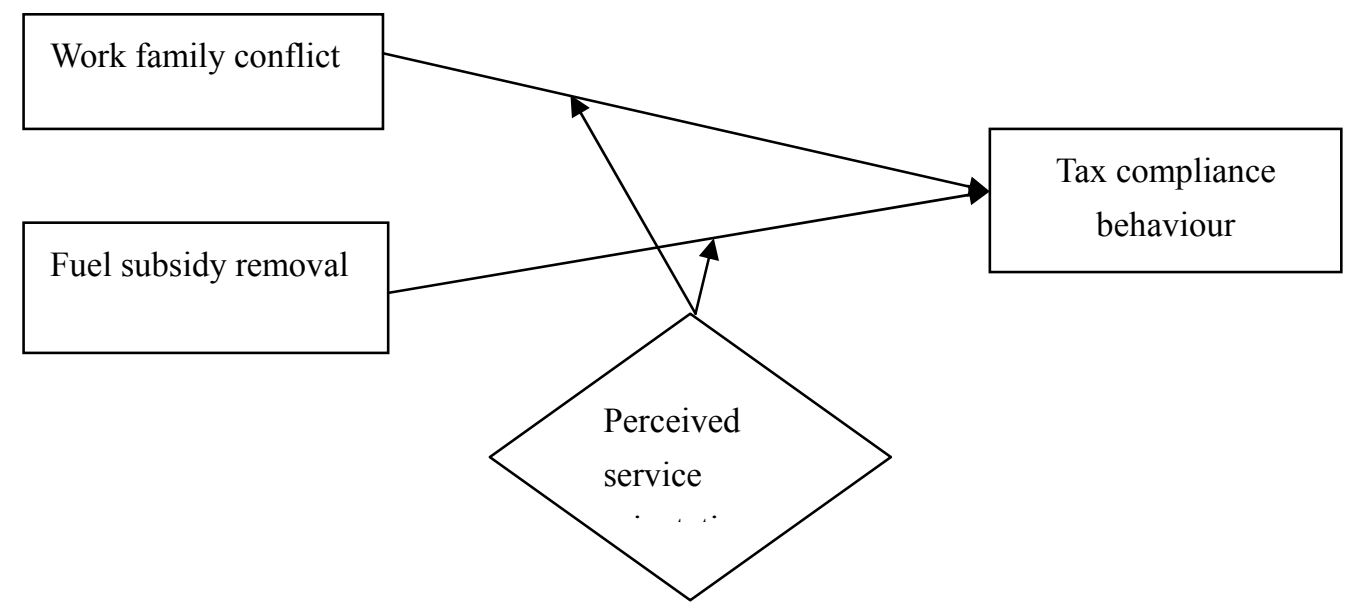

Figure 1. Research framework

\section{Material and Methods}

\subsection{Data Collection and Sample}

In trying to achieve the objective of this research, the survey instrument was employed in sourcing the relevant data from the SMEs taxpayers. As recommended by Hair, Black, Babin, and Anderson (2010), the survey involved series of pre-test and a pilot test before being administered to the respondents. As a result, discussions of the instrument were carried out by four experts from the industry, seven academicians (i.e. Four professors and three senior lecturers), as well as three staff of the respective States Internal Revenue Service's whom in one way contributed to the enhancement of the research instrument. In order to have an adequate number of responses to this study, the questionnaires were distributed to the SMEs taxpayers in two states (i.e. Kaduna and Kano states), north - west, Nigeria using stratified random sampling. A total of 281 usable responses was finally employed for this study. Of 281 participants, $54.8 \%$ were male, while the remaining $45.2 \%$ were female. 


\subsection{Measures}

\subsubsection{Tax Compliance Behaviour (TCB)}

Tax compliance behaviour was assessed using 15 - items adapted from Yankelovich, Skelly, and White (1984). All the participants were asked to indicate their response using 5 - point Likert scale anchored by $1=$ "strongly disagree" to $5=$ "strongly agree". The scale has been discovered to be reliable as documented by Richardson (2005). A sample of the tax compliance behaviour item is "Since a lot of rich people pay no taxes at all, if SMEs underpay a little, it's not a big deal".

\subsubsection{Work Family Conflict (WFC)}

Work family conflict was measured by the average of 18 - items from Carlson et al. (2000) work family conflict scale. For this construct, perception of the SMEs, owners/ managers were rated using a 5 point Likert scale ranging from (1) = "strongly disagree" to (5) = "strongly agree". A sample of work family conflict scale item is "The time I spend on family responsibilities often interfere with my business responsibilities".

\subsubsection{Fuel Subsidy Removal (FSR)}

Fuel subsidy removal was assessed based on Abdelrahim (2014) scales on fuel subsidy removal. Therefore, all the items used for fuel subsidy removal were rated on a 5 - point Likert scale anchored by $1=$ "strongly disagree" to $5=$ "strongly agree". A sample of the fuel subsidy removal item is " Fuel subsidy removal increases the cost of electricity consumption to SMEs".

\subsubsection{Perceived Service Orientation (PSO)}

Perceived service orientation was measured by the average of 5 - items from Gangl et al. (2013) perceived service orientation scale. In total participants were asked to indicate their response on a five point Likert scale as $(1=$ completely disagree; to $5=$ completely agree). A sample item is "Tax authorities does everything possible to serve SMEs and other people in general".

\section{Results}

\subsection{Measurement Model}

In assessing the construct validity, we followed a two-step modeling approach as recommended by Anderson and Gerbing (1988). In the process of ascertaining the construct validity of this research, firstly, the convergent validity and reliability were assessed first, followed by the discriminant validity, and finally the internal consistency reliability of the latent variables as shown in Table 1 and Table 2 respectively. Following Bagozzi, Yin and Phillips (1991); Fornell and Larcker (1981); Hair, Black, Babin, Anderson, and Tatham (2006) as bases, construct validity is ascertained if the indicator loadings are greater than 0.7 , composite reliability is greater than 0.7 , and the average variance extracted is greater than 0.5 .

Table 1. Result of measurement model

\begin{tabular}{ccccc}
\hline Construct & Items & Loadings & $\begin{array}{c}{ }^{\mathrm{a}} \text { Composite reliability } \\
(\mathrm{CR})\end{array}$ & $\begin{array}{c}{ }^{\mathrm{b}} \text { Average Variance Extracted } \\
\text { (AVE) }\end{array}$ \\
\hline Fuel subsidy removal & FSR01 & 0.7854 & 0.9225 & 0.5986 \\
& FSR02 & 0.7443 & & \\
& FSR03 & 0.8176 & & \\
& FSR04 & 0.7834 & & \\
& FSR05 & 0.7309 & & \\
& FSR06 & 0.7748 & & 0.5050 \\
& FSR07 & 0.8240 & & \\
& FSR08 & 0.7225 & & \\
Perceived service orientation & PSO01 & 0.7357 & 0.7536 & \\
& PSO03 & 0.7059 & & 0.6632 \\
\hline PSO04 & 0.6896 & & \\
\hline
\end{tabular}




\begin{tabular}{|c|c|c|c|c|}
\hline Construct & Items & Loadings & $\begin{array}{c}{ }^{\mathrm{a}} \text { Composite reliability } \\
\text { (CR) }\end{array}$ & $\begin{array}{c}{ }^{\mathrm{b}} \text { Average Variance Extracted } \\
\text { (AVE) }\end{array}$ \\
\hline \multirow{17}{*}{ Work family conflict } & TCB13 & 0.8153 & \multirow{17}{*}{0.9457} & \multirow{17}{*}{0.6641} \\
\hline & TCB14 & 0.7330 & & \\
\hline & TCB02 & 0.9116 & & \\
\hline & TCB04 & 0.6474 & & \\
\hline & TCB06 & 0.8192 & & \\
\hline & TCB07 & 0.7371 & & \\
\hline & TCB08 & 0.8309 & & \\
\hline & TCB09 & 0.9204 & & \\
\hline & WFC01 & 0.8703 & & \\
\hline & WFC10 & 0.8628 & & \\
\hline & WFC11 & 0.8739 & & \\
\hline & WFC12 & 0.5867 & & \\
\hline & WFC14 & 0.8739 & & \\
\hline & WFC15 & 0.5867 & & \\
\hline & WFC18 & 0.8658 & & \\
\hline & WFC05 & 0.8658 & & \\
\hline & WFC06 & 0.8719 & & \\
\hline
\end{tabular}

Note: FSR09, FSR10, FSR11, FSR12, FSR13, PSO02, PSO05 TCB03, TCB03, TCB05, TCB10, TCB12, TCB15, WFC02, WFC03, WFC04, WFC07, WFC08, WFC09, WFC13, WFC16, and WFC17 were deleted because of low loadings of less than 0.50 ; ${ }^{a}$ Composite Reliability $(\mathrm{CR})=$ (square of the summation of the factor loadings)/[(square of the summation of the factor loadings) + (square of the summation of the error variances)]; bAverage Variance Extracted $(\mathrm{AVE})=$ (summation of the square of the factor loadings) $/[($ summation of the square of the factor loadings) + (summation of the error variances)].

As part of the requirement for the measurement model. The researchers also evaluate the discriminant validity of the latent construct as represented in Table 2. Following Fornell and Lacker's (1981) recommendation, the average variance shared between each construct and its measures should exceed the variance shared between the construct and other constructs.

Table 2. Latent variable correlations and square roots of the average variance extracted

\begin{tabular}{ccccc}
\hline Construct & 1 & 2 & 3 & 4 \\
\hline 1. Fuel subsidy removal & $\mathbf{0 . 7 7}$ & & & \\
2. Perceived service orientation & -0.03 & $\mathbf{0 . 7 1}$ & & \\
3. Tax compliance behaviour & -0.20 & 0.12 & $\mathbf{0 . 8 1}$ & \\
4. Work family conflict & 0.13 & -0.08 & -0.29 & $\mathbf{0 . 8 1}$ \\
\hline
\end{tabular}

Source: The Researcher

As presented in Table 2, the absolute correlation values for each of the latent construct is less than the square root of the average variance extracted, thus an adequate discriminant validity of the constructs is reached (Hair et al., 2010).

\subsection{Structural Model}

Having done with the measurement model in the previous section. Here, the researchers emphasised on the result of the structural model based on 281 cases and 5000 bootstrap samples as shown in Table 3. Specifically, $t$ - 
values were used in either supporting or disproving the earlier hypotheses. Considering hypothesis 1 which predicted a significant negative relationship between work family conflict and tax compliance behaviour. Result (Table 3) revealed a significant negative relationship between work family conflict (WFC) and tax compliance behaviour (TCB), $(\beta=-0.23, \mathrm{t}=4.50, \mathrm{p}<0.01)$, supporting hypothesis 1 . In the same vein, hypothesis 2 also predicted a negative significant relationship between the fuel subsidy removal (FSR) and tax compliance behaviour (TCB). Result (Table 3) shows that fuel subsidy removal had a significant negative relationship with tax compliance behaviour $(\beta=-0.15, \mathrm{t}=3.12, \mathrm{p}<0.01)$, thus supporting hypothesis 2 .

Moreover, regarding the interacting effect of perceived service orientation on the relationship between work family conflict, fuel subsidy removal and tax compliance behaviour. As expected, the results shown in Table 3, indicated that the interaction terms representing work family conflict $x$ perceived service orientation $(\beta=-0.11, t$ $=1.26, \mathrm{p}<0.10$ ) was statistically significant, thus hypothesis 3 was fully supported. However, as captured in the previous section, it could be recalled that hypothesis 4 stated that perceived service orientation will moderate the relationship between the fuel subsidy removal and tax compliance behaviour. Results (Table 3) suggest that the interaction terms representing the fuel subsidy removal $x$ perceived service orientation was not statistically significant $(\beta=0.13, \mathrm{t}=0.72, \mathrm{p}>0.10)$.

Table 3. Path coefficients and hypotheses testing

\begin{tabular}{ccccccc}
\hline Hypotheses & Relation & Beta - values & Standard Error & T Statistics & P - values & Decision \\
\hline H1 & WFC - TCB & -0.23 & 0.05 & $4.50^{* * *}$ & 0.00 & Supported \\
H2 & FSR -> TCB & -0.15 & 0.05 & $3.12^{* * *}$ & 0.00 & Supported \\
H3 & WFC * PSO -> TCB & -0.11 & 0.09 & $1.26^{*}$ & 0.10 & Supported \\
H4 & FSR * PSO -> TCB & 0.13 & 0.17 & 0.72 & 0.24 & Not supported \\
& TCB (R - squared) & $14 \%$ & & & & \\
\hline
\end{tabular}

Note: ${ }^{* * *}$ Significant at 0.01 (1-tailed), ${ }^{* *}$ significant at 0.05 (1-tailed), * significant at 0.1 (1-tailed).

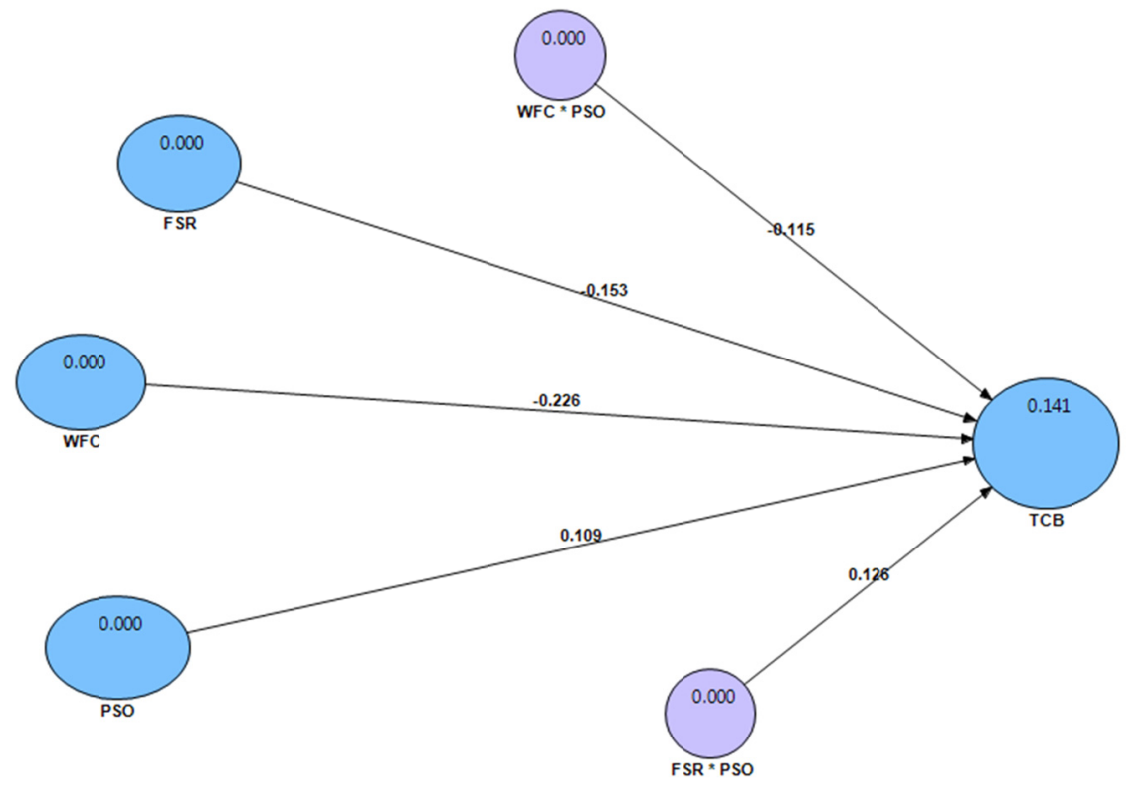

Figure 1. Results of the structural model analysis

As represented in Table 3 and Figure 1, hypotheses (1, 2, and 3) were supported, while hypotheses 4 was not supported. 
Regarding the R-squared values, the research model in Figure 1 explains $14 \%$ of the total variance in tax compliance behaviour, suggesting that work family conflict and fuel subsidy removal collectively explains $14 \%$ of the variance in tax compliance behaviour. It means other variables could account for the remaining $86 \%$. Even though, Falk and Miller (1992) recommended 10\% as acceptable R - squared value in researches. As such, on the basis of this threshold, the R - squared value of $14 \%$ can be considered acceptable.

\section{Discussions}

This study examined the interacting role of perceived service orientation on the relationship between work family conflict, fuel subsidy removal on tax compliance behaviour among the Nigerian SMEs owners / managers. The findings regarding the direct effects of work family conflict and fuel subsidy removal were related to tax compliance behaviour as expected. Since these findings represent one of the main contributions of this research, possible explanations of its direct effect could be explained from theoretical perspectives rather than relying on prior empirical studies. Hence, work family spillover theory Staines (1980), and social exchange theory (Blau, 1964) serves as the basis for the possible justifications of the new findings. Therefore, the work family spillover theory emphasizes that either system (i.e. Family or work) may have or possessed a spillover effect or influence on the other (Staines, 1980). This implies that, as work family conflict become tense individual taxpayers (SMEs owners/managers) may be faced with so many family obligations, hence the attention to other business obligations may be affected and vice versa. Similarly, the theory further highlighted that, satisfaction or dissatisfaction in one area of life may extend to other domains (conflict in the family may affect individual business obligations (tax payment and vice versa) (George \& Brief, 1990). This suggests further that as work, family burdens or obligation becomes severe, it has the possibility of affecting the financial position of the taxpayer. Because in meeting the pressing financial need of the family, the spillover effects may shift to his / her business environment, as a result may not be able to allow them to fulfill their business obligations (such as tax payment, salaries and wages, and other administrative cost).

In addition, the negative relationship also corroborates with Kossek and Ozeki (1998) who found that the presence of high work family conflict may create additional demands (e.g., Financial obligations to meet family pressure, which in turn may negatively affect tax payment as well as compliance behaviour of the taxpayers). The findings could be aligned to Kalliath and Kalliath (2013), and Shaffer and Joplin (2001) who conceived the ability of family interference with work demands to be negatively associated with job performance (this job performance could be the ability of the business to adhere to tax obligations and payments). As in the case of Nigeria, especially in the northern region of the country, where the literacy level is very low compared to other regions. The northern region where this study was conducted is highly characterized by extreme levels of poverty, this actually gives rise to extended family burdens and other form of dependency. Therefore, in the process of meeting the needs of this category of people, the spillover effects may in turn shift to their respective business domains.

This study also provided empirical support for the direct relationship between the fuel subsidy removal and tax compliance behaviour. Specifically, fuel subsidy removal has a negative influenced on other factors, such as the cost of business operation, effects on SMEs (Hoai \& Thang, 2013; Hope \& Singh, 1995; Kehinde et al., 2012; Odemero, 2013). Drawing from the tenets of social exchange theory (Blau, 1964), it emphasizes that individuals are psychologically indebted and thus compelled to return benefits they received in material or non-material form to the person that benefited them. On the other hand, the negative relationship is not surprising, because is consistent with (Taiwo, 2013) who revealed that fuel subsidy removal will compound extreme pressures on disposable income as well as intensifying further loss of tax revenues and higher cost of enforcing compliance. This implies that SMEs taxpayers', who experience more hardship in terms of trying to run their respective businesses, may perceive the government as being responsible. The possible reason is not far fetching because the revenue derived from the subsidy removal supposed to have been used to finance the infrastructural facilities which by extension may encourage the taxpayers' in keeping the covenant of reciprocity but were diverted to other ventures. Hence, affected the contract of reciprocity as revealed by this finding.

Likewise, regarding the interacting effect of perceived service orientation on the relationship between work family conflict and tax compliance behaviour. As expected the hypothesis is supported. One of the interesting aspect of this finding is that the presence of service orientation on the relationship between work family conflict and compliance behaviour made the relationship to be more negative. This is an indication that the effects of perceived service orientation had further strengthened the negative influence of work family conflict on taxpayers compliance behaviour, as such, it recommends that in the presence of service orientation, with an increase in work family conflict, SMEs owners / managers are more likely to be less compliant. This result came in the direction and statistical significance expected, indicating that work family conflict cum perceived service 
orientation will further reduce the level of compliance as shown by the respondents. This finding could be further supported by Nzotta (2007); and Odinkonigbo (2009) who claimed that, poverty and the extended family burden (for instance, financial obligations) may be seen as one of the causes of low level of tax compliance in Nigeria. It, however, disagrees with the earlier findings of Gangl et al. (2013) who found that taxpayers' who perceived a greater service orientation will be more willing to pay their taxes.

Additionally, the present study did not find support for the interacting effect of perceived service orientation on the relationship between the fuel subsidy removal and tax compliance behaviour. The results demonstrated that service awareness does not serve as an avenue in enlightening the taxpayers towards increasing their compliance level; as such service orientation does not stimulate the taxpayers. The lack of interacting effect of perceived service orientation might be as a result of participants of this study were not actually motivated by the activities of the relevant tax authorities targeting at benefiting the SMEs owners / managers. Even though, Locke (1968) reported that if people are to be motivated to behave in a rational way, such people need to see a good reason to act in the desired direction. One plausible reason could be the provision of services in the form of tax education, calls and other services which in return will make the taxpayers behave in the desired direction towards tax payment. Another possible explanation for the lack of support for these hypothesized relationships pertains to the notion of misregulations of service providers in the country. According to Feld and Frey (2007), and Wallschutzky (1984) improper treatment of taxpayers in the course of provision of services in the tax offices may determine their future compliance behaviour.

\section{Implications}

On the basis of the above findings and discussions, there are a few implications for policy makers (relevant tax authorities) as well as the SMEs, owners to take into consideration due to the importance of taxes to the survival of any economy. The importance of the interacting effect of perceived service orientation implies that authorities that are perceived as a service-oriented would yield a greater level of voluntary compliance among taxpayers. As such, suggests mutual cooperation with the taxpayers rather than forcing them to comply. Furthermore, in relation to perceived service orientation, ethical reorientation could be a promising avenue in reducing the likelihood of individual (taxpayers) engaging in deviant behaviour (such as low level of tax compliance) (Henle, Giacalone, \& Jurkiewicz, 2005).

In this study, the researchers outlined the following limitations that were unavoidably accompanied the research. Specifically, the study reported an R - squared of 14\%, suggesting that work family conflict, fuel subsidy as well as perceived service orientation were not the only predictors of tax compliance behaviour. Consequently, future research direction should look at the possibility of introducing other economic and noneconomic factors as a combine model. In addition, this study was entirely cross - sectional where data are collected at a point in time. To that end, inferences concerning the cause and effect nature of the study could not be made with certainty. Therefore, future studies should look at the possibility of employing longitudinal data in order to confirm these findings. In other ways, the study is only restricted to SMEs owners / managers as the only respondents, thence, future researches should also look at the possibility of incorporating other form of taxpayers in the consideration of sample size. For work family conflict, fuel subsidy removal as well as service orientation does not only affect SMEs owners/managers, it also extends to corporate entities, including this group will give room for more robust and generalisation of findings.

\section{References}

Abdelrahim, K. E. (2014). Economic impact of energy subsidy and subsidy reform measures: New evidence from Jordan. International Journal of Business and Social Research, 4(4), 98-110.

Alabede, J. O. (2012). An investigation of factors influencing taxpayers' compliance behaviour: Evidence from Nigeria (Unpublished $\mathrm{PhD}$ thesis). University Utara Malaysia.

Alabede, J. O., Ariffin, Z. Z., \& Kamil, I. (2011). Public governance quality and tax compliance behavior in Nigeria : The moderating role of financial condition and risk preference. Issues in Social and Environmental Accounting, 5(1/2), 3-24.

Allingham, M., \& Sandmo, A. (1972). Income tax evasion: A theoretical analysis. Journal of Public Economics, 1(3-4), 323-338. http://dx.doi.org/10.1016/0047-2727(72)90010-2

Anderson, J. C., \& Gerbing, D. W. (1988). Structural equation modeling in practice: A review and recommended two - step approach. Psychological Bulletin, 103, 411-423. http://dx.doi.org/10.1037/0033-2909.103.3.411

Aryee, S. (1992). Antecedents and outcomes of work-family conflict among married professional women: Evidence from Singapore. Human Relations, 45, 813-837. http://dx.doi.org/10.1177/001872679204500804 
Atawodi, O. W., \& Ojeka, S. A. (2012). Factors that affect tax compliance among small and medium enterprises in North Central Nigeria. International Journal of Business and Management, 7(12), 87-96. http://dx.doi.org/10.5539/ijbm.v7n12p87

Australian Tax Office. (2009). Retrieved May 22, 2014, from http://www.ato.gov.au/corporate/content.asp?doc=/ content/00107941.htm

Bagozzi, R. P., Yin, Y., \& Phillips, L. W. (1991). Assessing construct validity in organizational research. Administrative Science Quarterly 36(3), 421-458. http://dx.doi.org/10.2307/2393203

Bandura, A. (1977). Social learning theory. New York: General Learning Press.

Baron, R. M., \& Kenny, D. A. (1986). The moderator mediator variable distinction in social psychological research: Conceptual, strategic, and statistical considerations. Journal of Personality and Social Psychology, 51, 1173-1182. http://dx.doi.org/10.1037/0022-3514.51.6.1173

BBC News Magazine. (2013, May 12). Google, Amazon, Starbucks: The rise of tax shaming.

Becker, G. S. (1968). Crime and punishment: An economic approach. Journal of Political Economy, 76(2), 168-217. http://dx.doi.org/10.1086/259394

Blau, P. M. (1964). Exchange and power in social life. New York: John Wiley \& Sons, Inc.

Carlson, D. S., Kacmar, K. M., \& Williams, L. J. (2000). Construction and initial validation of a multidimensional measure of work-family conflict. Journal of Vocational Behaviour, 56(2), 249-276. http://dx.doi.org/10.1006/jvbe.1999.1713

Cheunjit, P. (2014). The culture of taxation: Definition and conceptual approaches for tax administration. Journal of Population and Social Studies, 22(1), 14-34. http://dx.doi.org/10.14456/jpss.2014.4

Chris, C. W., Coleen S. T., \& David, O. (2000). An expanded model of taxpayer compliance: Empirical evidence from the United States and Hong Kong. Journal of International Accounting, Auditing and Taxation, 9(2), 83-103. http://dx.doi.org/10.1016/S1061-9518(00)00027-6

Eisenhauer, J. G. (2008). Ethical preferences, risk aversion, and taxpayer behavior. The Journal of Socio-Economics, 37(1), 45-63. http://dx.doi.org/10.1016/j.socec.2007.01.030

Falk, R. F., \& Miller, N. B. (1992). A primer for soft modeling. Akron, OH: University of Akron Press.

Feld, L. P., \& Frey, B. S. (2007), Tax compliance as the result of a psychological tax contract: The role of incentives and responsive regulation. Law \& Policy 29, 102-120. http://dx.doi.org/10.1111/j.14679930.2007.00248.x

Fischer, C. M., Wartick, M., \& Mark, M. M. (1992). Detection probability and taxpayer compliance: A review of the literature. Journal of Accounting Literature, 11, 1-27.

Fornell, C., \& Larcker, D. F. (1981). Evaluating structural equation models with unobservable variables and measurement error. Journal of Marketing Research, 18(1), 39-50. http://dx.doi.org/10.2307/3151312

Frone, M. R., Yardley, J. K., \& Markel, K. S. (1997). Developing and testing an integrative model of the work-family interface. Journal of Vocational Behaviour, 50, 145-167. http://dx.doi.org/10.1006/jvbe. 1996.1577

Gangl, K., Muehlbacher, S., de Groot, M., Goslinga, S., Hofmann, E., Kogler, C., \& Kirchler, E. (2013). How can I help you? Perceived service orientation of tax authorities and tax compliance. Finanz Archiv: Public Finance Analysis, 69(4), 487-510. http://dx.doi.org/10.1628/001522113X675683

Geibart, N. (2014). Digging out the complexities of tax compliance. The Business, 32-33.

George, J. M., \& Brief, A. P. (1990). The economic instrumentality of work: An examination of the moderating effects of financial requirements and sex on the pay-life satisfaction relationship. Journal of Vocational Behaviour, 37, 357-368. http://dx.doi.org/10.1016/0001-8791(90)90050-C

Greenhaus, J. H., \& Beutell, N. J. (1985). Sources of conflict between work and family roles. Academy of Management Review, 10(1), 76-88.

Hair, J. F., Black, W. C., Babin, B. J., \& Anderson, R. E. (2010). Multivariate data analysis: A global perspective. New Jersey: Pearson Education, Inc.

Hair, J. F., Black, W. C., Babin, B. J., Anderson, R. E., \& Tatham, R. L. (2006). Multivariate data analysis (6th ed.). New Jersey: Prentice Hall. 
Henle, C. A., Giacalone, R. A., \& Jurkiewicz, C. L. (2005). The role of ethical ideology in workplace deviance. Journal of Business Ethics, 56, 219-230. http://dx.doi.org/10.1007/s10551-004-2779-8

Hoai, T. T. D., \& Thang, T. T. (2013, December). Hypothetical impacts of energy subsidy removal on firms in Vietnam, UNDP.

Hogan, J., Hogan, R., \& Busch, C. M. (1984). How to measure service orientation. Journal of Applied Psychology, 69(1), 167-173. http://dx.doi.org/10.1037/0021-9010.69.1.167

Hogg, M. A., \& Vaughan, G. M. (2005). Social psychology (4th ed.). Harlow: Pearson Education Ltd.

Hope, E., \& Singh, B. (1995). Energy price increases in developing countries. World Bank Policy Research Paper. No. 1442. Washington D. C.: World Bank.

Ikpeze, N. I., Soludo, C. C., \& Elekwa, N. N. (2004). Nigeria: The political economy of the policy process, policy choice and implementation. IDR. Retrieved from http://www.idrc.org.

Inland Revenue Board (IRB) Malaysia. (2009). Retrieved May 22, 2014, from http://www.hasil.gov.my

Iyobhebhe, J. (2011). Removal of fuel subsidy in Nigeria: The issues and challenges. Retrieved August, 5, 2014, $\mathrm{http}: / /$ www.nigeriapolitico.com/subsidy\%20.html

James, S., \& Alley, C. (2002). Tax compliance, self-assessment system and tax administration. Journal of Finance, and Management in Public Services, 2(2), 27-42.

James, S., \& Alley, C. (2004). Tax compliance, self-assessment and tax administration. Journal of Finance and Management in Public Services, 2(2), 27-42.

Kalliath, P., \& Kalliath, T. (2013). Does job satisfaction mediate the relationship between work-family conflict and psychological strain? A study of Australian social workers. Asia Pacific Journal of Social Work and Development, 23(2), 91-105. http://dx.doi.org/10.1080/02185385.2013.793019

Katz, E., \& Lazarsfeld, P. F. (1955). Personal influence: The part played by people in the flow of mass communications. Glencoe, IL: Free Press.

Kehinde, A., Kyade. I. K., Felix, A. O., Musibau, O., \& Ishola, A. (2012). Fuel subsidy, agricultural sector, petroleum, budgetary allocation. International Journal of Humanities and Social Science Invention, 1(1), 20-29.

Kirchler, E., Hoelzl, E., \& Wahl, I. (2008). Enforced versus voluntary tax compliance: The "slippery slope" framework. Journal of Economic Psychology 29, 210-225. http://dx.doi.org/10.1016/j.joep.2007.05.004

Kirchler, E., Muelbacher, S., Kastlunger, B., \& Wahl, I. (2007). Why pay taxes? A review of tax compliance decisions. Working paper No 07-03, Georgia State University, Altanta.

Kossek, E., \& Ozeki, C. (1998). Work-family conflict, policies, and the job-life satisfaction relationship: A review and directions for organizational behavior-human resources research. Journal of Applied Psychology, 83(2), 139-149. http://dx.doi.org/10.1037//0021-9010.83.2.139

Manaf, N. A., Hasseldine, J., \& Hodges, R. (2005). The determinants of Malaysian land taxpayers' compliance attitude. eJournal of Tax Research, 3(2), 206-221.

McBarnett, D. (2003). When compliance is not the solution but the problem: From changes in law to changes in attitude. In V. Braithwaite (Ed.), Tax democracy: Understanding tax avoidance and evasion. Aldershort: Ashgate Publishing Ltd.

Muhammad, A. (2012, September 7). Kano state shuts 30 schools over tax evasion. Vanguard. Kano.

Mustafa, H. H. (1997). An evaluation of the Malaysian tax administrative system and taxpayers' perceptions towards self-assessment system, tax law fairness and tax law complexity (Unpublished manuscript). Universiti Utara Malaysia, Malaysia.

NAN. (2014). Nigeria's tax revenue ratio to GDP drops. Premium Times.

New Sabah Times English. (2013, June 20). IRB solves nearly 1.9mil tax evasion cases in 2012.

Nur-tegin, K. D. (2008). Determinants of business tax compliance. The B.E. Journal of Economic Analysis \& Policy, 8(1), 1-26. http://dx.doi.org/10.2202/1935-1682.1683

Nwafor, M., Ogujiuba, K., \& Asogwa, R. (2006). Does subsidy removal hurt the poor? Evidence from computable general equilibrium analysis. African Institute for Applied Economics. 
Nzotta, S. M. (2007). Tax evasion problems in Nigeria: A critique. The Nigerian Accountant, 12(1), 40-43.

Odemero, A. F. (2012). Price transmission and households demand elasticity for frozen fish under fuel subsidy reform in Delta state, Nigeria. International Journal of Food and Agricultural Economics, 1(1), 119-127.

Odinkonigbo, J. J. (2009). Rethinking the Nigeria's tax policy towards achieving tax compliance (Unpublished doctoral thesis). York University, Toronto.

OECD. (2010). Survey of trends and developments in the use of electronic services for taxpayerservicedelivery. Retrieved from http://www.oecd.org/dataoecd/20/49/45035933.pdf

Palil, M. R., \& Mustapha, A. F. (2011). Factors affecting tax compliance behaviour in self assessment system. African Journal of Business Management, 5(33), 12864-12872. http://dx.doi.org/10.5897/AJBM11.1742

Palil, M. R., Hamid, M. A., \& Hanafiah, H. M. (2013). Taxpayers compliance behaviour: Economic factors approach. Journal Pengurusan, 38, 75-85.

Paying Taxes. (2014). The global picture. A comparison of tax systems in 189 economies worldwide.

Raven, B. H. (1993). The bases of power: Origins and recent development. Journal of Social Issues, 49(4), 227-251. http://dx.doi.org/10.1111/j.1540-4560.1993.tb01191.x

Richardson, G. (2005). Determinants of tax evasion: A cross-country investigation. Journal of International Accounting, Auditing and Taxation, 15(2), 150-169. http://dx.doi.org/10.1016/j.intaccaudtax.2006.08.005

Roth., J. A., Scholz, J. T., \& Dry-Witte, J. T. (1989). Taxpayer compliance: An agenda for research (Volume 1). Philadelphia: University of Pennsylvania Press.

Saad, N. (2014). Tax knowledge, tax complexity and tax compliance: Taxpayers' view. Procedia Social and Behavioral Sciences, 109(1), 1069-1075. http://dx.doi.org/10.1016/j.sbspro.2013.12.590

Shaffer, M. A., \& Joplin, J. R. W. (2001). Work-family conflict on international assignments: Time- and strain based determinants and performance effort consequences. Academy of Management Proceedings, 11-16. http://dx.doi.org/10.5465/apbpp.2001.6133447

Shekari, I. (2014, April 14). Tax evasion in Kaduna state. Premium Times.

Slemrod, J. (1992). Why people pay taxes, tax compliance and enforcement. Ann Arbor: University of Michigan Press.

Slemrod, J., Blumenthal, M., \& Christian, C. (2001). Taxpayer response to an increased probability of audit: Evidence from a controlled experiment in Minnesota. Journal of Public Economics, 79(3), 455-483. http://dx.doi.org/10.1016/S0047-2727(99)00107-3

Smith, K. W., \& Stalans, L. J. (1991). Encouraging tax compliance with positive incentives: A conceptual framework and research directions. Law \& Policy 13, 35-53. http://dx.doi.org/10.1111/j.1467-9930.1991. tb00056.x

Song, Y. D., \& Yarbrough, T. E. (1978). Tax ethics and taxpayer attitudes: A survey. Public Administration Review, 38(5), 442-452. http://dx.doi.org/10.2307/975503

Staines, G. L. (1980). Spill over versus compensation: A review of the literature on the relationship between work and non work. Human Relations, 33, 111-129. http://dx.doi.org/10.1177/001872678003300203

Stalans, L., \& Lind, E. A. (1997). The meaning of procedural fairness: A comparison of taxpayers' and representatives' views of their tax audits. Social Justice Research, 10, 311-331. http://dx.doi.org/10.1007/ BF02683306

Sutinen, J. G., \& Kuperan, K. (1999). A socio-economic theory of regulatory compliance. International Journal of Social Economics, 26(1/2/3), 174-193. http://dx.doi.org/10.1108/03068299910229569

Taiwo, K. (2012). The fuel subsidy saga in Nigeria: A drawback resulting from government inefficiency (Part 1). Retrieved September 20, 2014, from http://taiwokehinde-mymind.blogspot.com/2012/04/fuel-subsidy-sagain-Nigeriadrawback.html

Taiwo, O. (2013). An interview with Taiwo Oyedele on the tax implications of Nigeria's rebased GDP (May).

Tanko, M. (2014, June 18). Kaduna shuts 25 private schools, MFB over tax evasion. Punch.

Torgler, B. (2005). Speaking to theorists and searching for facts: Tax morale and tax compliance in experiments. Journal of Economic Surveys, 16(5), 77-89. 
Wallschutzky, I. G. (1984). Possible causes for tax evasion. Journal of Economic Psychology, 5, 374-384. http://dx.doi.org/10.1016/0167-4870(84)90034-5

Wickens, C. D. (1996). Designing for stress. In J. Driskell, \& E. Salas (Eds.), Stress and human performance (pp. 279-295). Mahwah, NJ: Erlbaum.

Yankelovich, S., \& White, C. (1984). Survey of Taxpayer Attitudes. Washington DC.

Young, J. C. (1994). Factors associated with non-compliance: Evidence from the Michigan tax amnesty program. Journal of American Taxation Association, 16(2), 82-105.

\section{Copyrights}

Copyright for this article is retained by the author(s), with first publication rights granted to the journal.

This is an open-access article distributed under the terms and conditions of the Creative Commons Attribution license (http://creativecommons.org/licenses/by/3.0/) 